\title{
Advanced Cold Roof Construction in a Temperate Climate
}

\author{
Mark Siddall $^{\mathrm{a}}$, Emmanuel Essah ${ }^{\mathrm{b}}$, Jack Harvie-Clark $^{\mathrm{c}}$ \\ a LEAP: Lovingly Engineered Architecture, Durham, UK. \\ $b$ School of The Built Environment. University of Reading, Reading, UK. \\ c Apex Acoustics, Gateshead, UK.
}

\begin{abstract}
Cold pitched roofs constitute $80 \%$ of domestic roofs in the UK and are commonly used when constructing new dwellings. They typically have horizontal insulation at ceiling level and a ventilated volume of cold air above. As the heat loss from low energy dwellings is reduced moisture risks increase, unless accompanied by ventilation and/or airtight construction. Current research suggests a ventilation slot is required in the U.K. climate - even in airtight dwellings. Whilst theoretical models can and should inform design, they are of limited use if their real-world performance is not verified.

This paper examines the hygrothermal performance of a sealed (unvented), windtight, cold roof with horizontal blown mineral wool insulation located above an airtight house located in Northern England. The roof has been monitored over the duration of 24 months. The research has assessed the viability of such roofs in the UK climate. The results are somewhat surprising, counter intuitive and defy conventional expectations.
\end{abstract}

Peer-review under the responsibility of the organizing committee of the ICMB21.

Keywords: cold roof; moisture, airtightness; hygrothermal; mould risk, low energy; Passivhaus.

\section{Introduction/Background}

Cold pitched roofs, which constitute $80 \%$ of domestic roofs in the UK [1], are commonly used when constructing new dwellings. They typically have insulation at the horizontal ceiling level and a volume of cold air above. Poorly ventilated cold roofs are associated with high humidity - rendering such roofs vulnerable to condensation formation and mould growth.

In the UK context Essah et al. [2] examined the effects of roof underlay on condensation and moisture transport in cold roofs using a theoretical HAM model. The analysis did not suggest a windtightness standard for the roof space but did consider limiting dwelling air leakage to 1.5 ach @ 50pa whilst also recommending eaves ventilation. To avoid a vapour permeable underlay (VPU) being overwhelmed by the accumulation of condensate, Essah later observed "the rate at which moisture vapour enters the roof from rooms below must be equal to the rate at which it leaves through the underlay." [3]

In considering the impact of thermal bypass and moisture loads upon the building fabric, dwelling airtightness standards were reviewed. It is understood from Roels and Langmans [4] note Straube [5] proposed tightening Di Lenardo's 1995 [6] limit to $0.0047 \mathrm{~m}$ 3/ $\mathrm{m}^{2} / \mathrm{h} / \mathrm{Pa}\left(0.24 \mathrm{~m}^{3} / \mathrm{h} . \mathrm{m}^{2} @ 50 \mathrm{~Pa}\right)$. Straube's suggestion correlates with Di Lenardo's more recent conclusions (shown in Table 1) where the Maximum Permissible Air Leakage Rate was determined using a vapour barrier (Sd-Value 3.33m) on the warm side and interior conditions of $21^{\circ} \mathrm{C}$ and $35 \% \mathrm{RH}$ [7]. In a Northern European climate, presenting the results of calculations developed to prevent moisture accumulation and moisture damage in roof spaces, Feist [8] recommended an air permeability of $0.5 \mathrm{~m}^{3} / \mathrm{h} . \mathrm{m}^{2} @ 50 \mathrm{pa}$ where the fabric is diffusion closed and $2 \mathrm{~m} / \mathrm{h} . \mathrm{m}^{2} @ 50 \mathrm{pa}$ where the fabric is diffusion open.

With regard to thermal bypass, windtightness standards have also been reviewed. In 1996 Uvsløkk [9] proposed limiting heat loss caused by air movement (namely wind washing) to less than $5 \%$ of the notional U-value. Where the notional U-value was $0.27 \mathrm{~W} / \mathrm{m}^{2} \mathrm{~K}$ the windtightness requirement was $0.05 \mathrm{~m}^{3} / \mathrm{m}^{2} \mathrm{~h} \mathrm{~Pa}\left(1.4 \mathrm{E}-5 \mathrm{~m}^{3} / \mathrm{m}^{2} \mathrm{~s} \mathrm{~Pa} ; 2.5 \mathrm{~m} / \mathrm{h} . \mathrm{m}^{2} @ 50 \mathrm{~Pa}\right)$. A windtightness standard for other $\mathrm{U}$-values can be extrapolated by assuming a linear flow-pressure relationship. Table 2 below shows the targets.

This paper presents findings that examine the hygrothermal performance of a sealed (unvented), super-insulated, wind-tight, cold roof located in the North of England. The findings form the basis of ongoing research that will determine the performance and viability of such roofs in the UK climate. The research presented here explores a scenario whereby condensation risk within a cold roof space is reduced by limiting both controlled and uncontrolled ventilation. As such this paper advances and extends the research presented in Essah et al [2].

\begin{tabular}{|c|c|}
\hline $\begin{array}{l}\text { Sd-Value of Outermost Uninsulated (Non- } \\
\text { Vented) Layer of the Wall Assembly (meters) }\end{array}$ & $\begin{array}{r}\text { Maximum Permissible Air } \\
\text { Leakage Rates }\left(\mathrm{m}^{3} / \mathrm{h} \cdot \mathrm{m}^{2} @ 50 \mathrm{~Pa}\right)\end{array}$ \\
\hline 13.3 to $<3.33$ & 0.12 \\
\hline 3.33 to $<1.18$ & 0.24 \\
\hline 1.18 to $<0.25$ & 0.36 \\
\hline$>0.25$ & 0.48 \\
\hline \multicolumn{2}{|c|}{$\begin{array}{l}\text { Table 1: Based upon Di Lenardo (2000). NOTE: For the purposes of this paper } \\
\mathrm{ng} /(\mathrm{Pa} \bullet \mathrm{s} \bullet \mathrm{m} 2) \text { has been converted to Sd-Value and air leakage rates, assuming a linear } \\
\text { flow coefficient, have been converted from } 75 \mathrm{pa} \text { to } 50 \mathrm{pa} \text {. }\end{array}$} \\
\hline
\end{tabular}

\begin{tabular}{|c|c|}
\hline U-value $\left(\mathrm{W} / \mathrm{m}^{2} \mathrm{~K}\right)$ & $\begin{array}{c}\text { Windtightness Target } \\
\left(\mathrm{m}^{3} / \mathrm{h} . \mathrm{m}^{2} @ 50 \mathrm{~Pa}\right)\end{array}$ \\
\hline 0.27 & 2.5 \\
\hline 0.15 & 1.4 \\
\hline 0.1 & 0.9 \\
\hline 0.05 & 0.5 \\
\hline
\end{tabular}

Table 2: Leakage criteria inc. joints) after Uvsløkk (1996), where heat loss is limited to $5 \%$ of the notional U-value. 


\section{Design and Measurement}

In situ measurements were conducted at a 2-storey dwelling with an internal volume $\left(\mathrm{Vn}_{50}\right)$ measured as $314.6 \mathrm{~m}^{3}$; envelope area $311.1 \mathrm{~m}^{2}$. The loft, with floor area of $66.8 \mathrm{~m}^{2}$, has been fitted with unbonded, glass mineral wool insulation (thickness $650 \mathrm{~mm}$ ) placed on the horizontal plane, envelope area $187.2 \mathrm{~m}^{2} ; \mathrm{Vn}_{50} 116.3 \mathrm{~m}^{3}$. The design U-value of the roof is $0.06 \mathrm{~W} / \mathrm{m}^{2} \mathrm{~K}$.

Altogether 30 sensors monitoring temperature (surface and air), relative humidity and $\mathrm{CO}_{2}$ were placed in strategic locations within the roof space and the house. Positions Ext, A2, C2 and D2 are reported here. A weather station was installed on the roof top at a height of $8.5 \mathrm{~m}$ above ground level. Calibrated sensors were logged every 5 minutes, using an Eltek data logger. The loft has been monitored over the duration of 24 months. As a Certified Passivhaus, the dwelling has balanced ventilation

\section{Analysis and Results}

In 2017 the dwelling had a measured airtightness of 0.31 ach@50pa (q50=0.31 m³ $\left./ \mathrm{m}^{2} @ 50 \mathrm{pa}\right)$ and the unvented loft had a measured air leakage of 7.9 ach@50pa (q50=4.9 m³/h.m²@50pa) with a humidity variable underlay $(0.1 \mathrm{MNs} / \mathrm{g}$; Sd-Value $0.02 \mathrm{~m})$. In January $2019, \mathrm{CO}_{2}$ decay tests were undertaken within the loft. The calculated background ventilation rate was 0.27 ach $\left(0.17 \mathrm{~m}^{3} / \mathrm{m}^{2}-\mathrm{h}\right)$. In 2020, at the end of the monitoring period, the dwelling had a measured airtightness of 0.49 ach@50pa (q50 $\left.=0.50 \mathrm{~m}^{3} / \mathrm{h} \cdot \mathrm{m}^{2} @ 50 \mathrm{pa}\right)$ and the unvented loft had a measured air leakage of 8.12 ach@50pa (q50=5.0 $\left.\mathrm{m}^{3} / \mathrm{h} \cdot \mathrm{m}^{2} @ 50 \mathrm{pa}\right)$. Following co-pressurisation tests (positive pressure $0.150 \mathrm{~m} / \mathrm{h} \cdot \mathrm{m}^{2} @ 50 \mathrm{pa}$, negative pressure $0.270 \mathrm{~m}^{3} / \mathrm{h} \cdot \mathrm{m}^{2} @ 50 \mathrm{pa}$ ) the calculated mean permeability of the air barrier at the attic floor interface was estimated as $0.21 \mathrm{~m}^{3} / \mathrm{h}_{\mathrm{m}} \mathrm{m}^{2} @ 50 \mathrm{pa}$ (Effective Leakage Area $698 \mathrm{~mm}{ }^{2}$ ). Increased dwelling air leakage arose from a worn/damaged door seal, measurement uncertainty and possible boiler panel leakage. Data analysis was categorised based on the Heating Season (Oct-Apr) and the No-heating Season (Apr to Sep).

\subsection{Profiling (Temperature \& $R H)$}

Although the profile of the temperatures collected in the loft generally followed that of the external conditions, they were warmer, though significant fluctuations did occur (between $-7^{\circ} \mathrm{C}$ and $20^{\circ} \mathrm{C}$ ). Similar trends were observed during the No-heating Season (NoHS) but ranged from $1{ }^{\circ} \mathrm{C}$ to $37^{\circ} \mathrm{C}$. Variations in the $\mathrm{RH}$ profiles were similar with higher RH levels observed in the loft during the heating season due to the external conditions. The Heating Season (HS) was considered for further analyses.

\subsection{Mould Risk Index (MRI)}

A Mould Risk Index (MRI) was developed based upon concepts proposed by [10] and [11]. Values $>1$ indicate mould risk. A daily average was used in these calculations for the HS dataset. During the winter/heating season, the northern side showed a slightly higher MRI with $20.4 \%$ of the data $\geq 1$. Similarly, the ridge showed a slightly elevated MRI profile with $23.3 \%$ of the measured data $\geq 1$. The lowest MRI occurred on the south facing roof which recorded $15.6 \%$ exceedance. The MRI of the roof space is much lower than external conditions where $51 \%$ of the data showed an MRI $\geq 1$.

\section{Conclusions}

For an airtight, super insulated dwelling with an unvented roof the following conclusions are made: (1) As expected, RH levels in the loft are higher in the HS compared to the NoHS. (2) Largely due solar gains the MRI values show the risk of mould formation in the loft is lower than those occurring in external conditions. (3) These results extend the UK's understanding about the performance of cold roofs with horizontal insulation, however, further research is required to determine whether the observations made here can be replicated in a manner that will inform the design and development of advanced low energy cold roofs.

\section{Acknowledgements}

The authors would like to thank Richard and Helen Hardill for placing their house at the research team's disposal for the duration of these measurements. We also thank Stephen Wise of Knauf Insulation for sponsoring the research.

\section{References}

[1] Sanders, C.H. (2006) Modelling condensation and airflow in pitched roofs, Building Research Establishment (BRE) information paper, IP 05/06, BRE Press, Garston, Watford, UK, pp. 1-5. [2] Essah E., et al. (2009) Condensation and moisture transport in cold roofs: effects of roof underlay, Building Research \& Information, 37:2, 117-128 [3] Essah E. (2012) Domestic Cold Pitched Roofs in the UK - Effect of Using Different Roof Insulation Materials, International Journal of Ventilation, Volume 11 No 3 December 2012, ISSN 1473-3315 [4] Roels and Langmans J. (2016) Highly insulated pitched roofs resilient to airflow patterns: guidelines based on a literature review, Energy and Buildings [5] Straube, J. 2011. High Performance Building Enclosures. Somerville, MA: Building Science Press in Roels and Langmans J. (2016) Highly insulated pitched roofs resilient to airflow patterns: guidelines based on a literature review, Energy and Buildings [6] Di Lenardo, B., et al. (1995), Technical guide for air barrier systems for exterior walls of low-rise buildings, Technical report, Canadian Construction Materials Centre, NRC, Ottawa, Ontario. [7] Di Lenardo B. (2000) A Method for Evaluating Air Barrier Systems and Materials, Construction Technology Update No. 46, National Research Council of Canada [8] Feist, W. (2005) Hochwärmegedämmte Dachkonstruktionen: Konsequenzen für hochwärmegedämmte Däche, Arbeitskreis kostengunstige Passivhauser Phase III, Protokollband Nr 29, Passivhaus Inst., Darmstadt [9] Uvsløkk S. (1996) The Importance of Wind Barriers for Insulated Timber Frame Constructions, Journal of Building Physics. [10] Hukka and Viitanen (1999). Wood Science and Technology 33 (1999) 475-485, SpringerVerlag. [11] L Hagentoft, C.-E., et al. (2008) Mould growth control in cold attics through adaptive ventilation, Session W2B - Moisture Sensitive Construction, Building Physics 2008, 8th Nordic Symposium, Copenhagen, Denmark, Lyngby ISBN 978-87-7877-265-7, 3, pp. 1237-1244. 